\title{
Cytokine Induced Killer (CIK) Cells Based Adoptive Immunotherapy
}

\author{
Timalsena $\mathrm{S}^{1^{*}}$, Lamichhane $\mathrm{PP}^{2}$ \\ ${ }^{1}$ Department of Pharmacology, ${ }^{2}$ Department of Microbiology, \\ Faculty of Medicine, Siriraj Hospital, Mahidol University, Bangkok Noi, Bangkok, Thailand
}

\author{
Keywords \\ Cancer, Cytokine induced killer (CIK) \\ cells, Immunotherapy, Viral infection. \\ Corresponding author \\ *Sunita Timalsena \\ Department of Pharmacology, \\ Faculty of Medicine Siriraj Hospital, \\ Mahidol University, Bangkok Noi, \\ Bangkok, Thailand \\ E-mail: sunitatimalsena@ymail.com
}

\begin{abstract}
Cytokine induced killer (CIK) cells has been increasingly used in adoptive immunotherapy against various cancers and viral infections. This review summarizes the basic overview of CIK cells as a therapeutic immunocyte. Herein, the basic concepts on CIK cells, their general characteristics, approaches in enhancing their functions, cytotoxic mechanism of CIK cells and their therapeutic benefits in tumors and viral infections are explored.
\end{abstract}

\section{INTRODUCTION}

Immunotherapy has emerged as a promising treatment option to boost immune response to defense against diseases and infections. The two immunotherapeutic options include active and passive immunotherapy. Active immunotherapy mainly refers to vaccines, immune adjuvants and cytokines which can activate endogenous immune system. On the other hand, the latter consists of immune modulating antibody-based therapy and adoptive immunotherapy which provides or strengthen immune reaction in patients by infusing antibodies or effector cells produced in vitro ${ }^{1}$.

\section{ADOPTIVE IMMUNOTHERAPY}

Over the past two decades, adoptive transfer of immunocytes has been increasingly used in treatment of cancers and viral infections ${ }^{2}$. The immunocytes for adoptive immunotherapy falls into two distinct categories. The first included lymphokine activated killer cells (LAK cells), cytokine induced killer cell (CIK cells) and natural killer (NK cells) that recognizes antigens in major histocompatibility complex (MHC) unrestricted manner. The other group included tumor infiltrating lymphocytes (TIL) and cytotoxic T lymphocytes (CTL) that recognize antigens presented by MHC molecules ${ }^{1}$. Previously, TIL and LAK used to be the best candidate for adoptive immunotherapy. However, limitations to obtain sufficient number of immune effectors cells, higher alloreactivity and inability to show antitumor property effectively attracted the researchers to seek for additional and better-tolerated strategy ${ }^{3}$. With the initial report of Schmidt-Wolf et $a l^{4}$ (1991) CIK cells has been identified as a promising candidate of adoptive immunotherapy that holds all the desired properties.

\section{CYTOKINE INDUCED KILLER CELLS AND THEIR GENERAL CHARACTERISTICS}

CIK cells are ex-vivo expanded T cells that display phenotypic and functional characteristics of both NK cells and cytotoxic $\mathrm{T}$ cells ${ }^{5}$. As these cells were generated under the influence of cytokines and mediate the potent MHCunrestricted cytotoxicity against various types of cancer, 
they were named as "cytokine induced killer" cells. Briefly, CIK cells were generated by culturing interferon gamma (IFN- $\gamma$ ) activated human peripheral blood mononuclear cells (PBMC) in presence of cluster of differentiation 3 (CD3) antibody, interleukin 1 (IL-1) and IL-2 for 21 days ${ }^{4,6,7}$. These ex-vivo expanded cells were used for targeted treatment of human disease $\mathrm{e}^{1,8}$.

The CIK cells consisted of heterogeneous subsets based on surface expression of CD3 and CD56 molecules. The major population positive for both $\mathrm{CD} 3$ and $\mathrm{CD} 56\left(\mathrm{CD}^{+}{ }^{+} \mathrm{CD} 56^{+}\right)$ (40 - 80\%) exhibited MHC unrestricted antitumor activity against malignant cells lines and believed to be the type II NK-T cells ${ }^{9-12}$. The remaining other populations included; $\mathrm{CD}^{+}{ }^{+}$D56 - (T cells, $20-60 \%$ ), and a small fraction of CD3$\mathrm{CD}^{+} 6^{+}$(NK cells, $\left.<10 \%\right)$ cells ${ }^{11}$.

$\mathrm{CD}^{+} \mathrm{CD}^{2} 6^{+}$cells are rare $(1 \%$ to $5 \%)$ in human PBMC. However, enhanced increase in this major effector population was achieved during ex-vivo expansion ${ }^{13}$. Moreover, the degree of expansion of $\mathrm{CD}^{+} \mathrm{CD} 56^{+}$cells vary among individual patients (mostly from three to thousand folds) $)^{4,6,9,14}$. Additionally, the $\mathrm{CD}^{+}{ }^{+} \mathrm{CD} 56^{+}$cells were derived from $\mathrm{CD}^{+} \mathrm{T}$ cells suggesting their cytotoxic nature ${ }^{9}$.

\section{SOURCE FOR CIK CELLS}

PBMC is given the first priority to generate these cells in humans ${ }^{4,15}$. However, expansion of human CIK cells from cord blood had been achieved ${ }^{16,17}$. Moreover, CIK cells were generated from splenocytes ${ }^{18}$ thymus $^{13,19}$ lymph nodes $^{20}$ and bone marrow ${ }^{19}$ of murine models.

\section{IMPROVING CIK CELL PROLIFERATION AND FUNCTION}

Since the first report of CIK cells by Schmidt-Wolf et $a l^{4}$ in 1991, various groups of researchers focused on improving both the expansion and anti-tumor cytotoxicity of CIK cells. The use of cytokines other than IL-2 or the co-culture of CIK cells with dendritic cells (DCs) and even the suppression of regulatory $\mathrm{T}$ cells (Tregs) within the CIK cell culture are the major modification being performed ${ }^{21-24}$. As such, use of various cytokines and antibodies like IL-6 ${ }^{25} \mathrm{IL}-15^{26,27}$, IL-21 ${ }^{28}$, and anti-CD28 $8^{13,29}$. These modifications enhanced the expansion and antitumor activity of CIK cells.

CIK cells primed with dendritic cells (DC-CIK cells) have been shown to promote their functions. As such, metastatic non-small cell lung cancer ${ }^{30}$ cervical cancer $^{31}$ advanced renal cell carcinoma ${ }^{32}$ and colorectal cancer $^{33}$ patients receiving DC-CIK cells improved the immune function, reduced the recurrence rate and prolonged the survival time. This might be due to reduced expansion of Treg cells ${ }^{34}$; however the detailed underlying mechanism is still unknown.

\section{CYTOTOXIC MECHANISM OF CIK CELLS}

CIK cells are endowed with potent MHC-unrestricted cytotoxicity against both syngeneic and allogenic hematological and solid malignancies. The antitumor activity is mainly associated with $\mathrm{CD} 3^{+} \mathrm{CD} 56^{+}$fraction as this fraction of cells has higher proportion of $\mathrm{CD}^{+}$cells. The exact mechanism involved in tumor recognition and killing by CIK cells is not completely known. However, cytotoxic granules like perforin and granzymes were proposed to be a mediator of cytolysis ${ }^{35}$ as shown in Fig 1. It is believed that CIK cells approach the target cells by chemotaxis, and then release a number of toxins and chemicals into the medium to induce the apoptosis, necrosis and lysis of target cells. That's why in the early stage (5 hours) CIK cells induce apoptosis while in later stage (14 hours) they induce necrosis for cell lysis ${ }^{36}$.

Fig 1: Mechanism of cytolysis of tumor cells by CIK cells (Perforin and granzymes released by CIK cells in tumor environment cause lysis of the tumor cells)

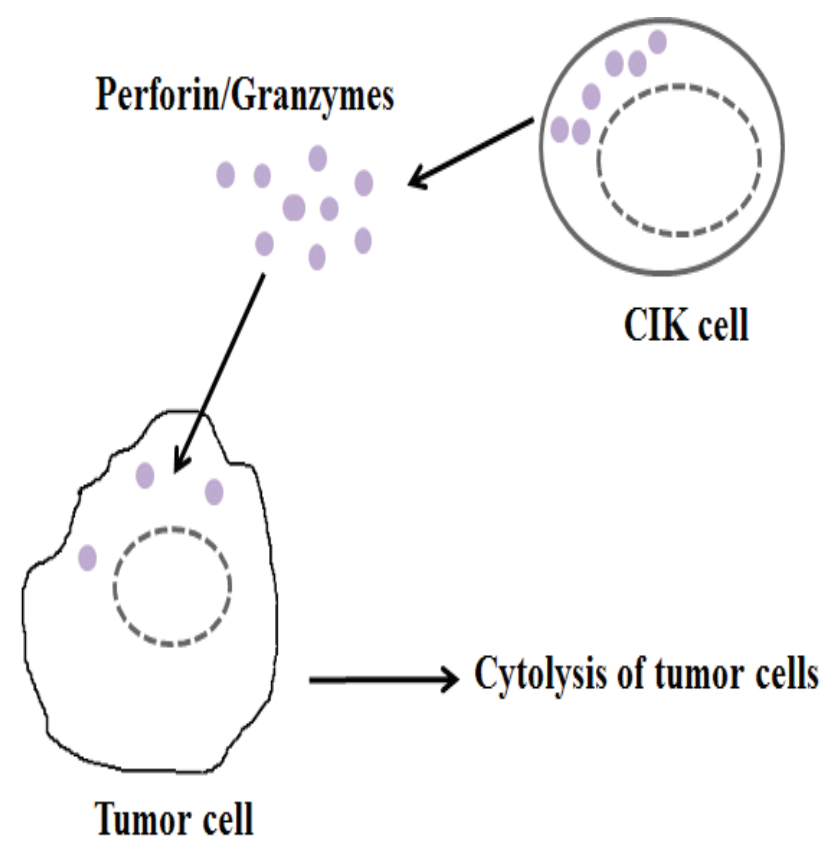

\section{CIK CELLS IN IMMUNOTHERAPY}

The dual $\mathrm{T}_{\mathrm{H}} 1$ and $\mathrm{NK}$ properties that can kill abnormal cells such as cancerous cells have promoted these CIK cells as a unique immunotherapeutic approach ${ }^{3,18,37}$. There are 
numerous research groups who have proven the efficacy and safety of CIK cells to treat a variety of cancers through clinical studies. Outcome of some of those clinical trials is as shown in Table 1.

Table 1: CIK cell based oncotherapy in phase-I clinical trials

\begin{tabular}{|c|c|c|c|}
\hline Cancer type & Cases & $\begin{array}{c}\text { Clinical Response } \\
\text { (Cases) }\end{array}$ & Ref \\
\hline $\begin{array}{l}\text { Colon carcinoma; } \\
\text { Follicular } \\
\text { lymphoma; Renal } \\
\text { cell carcinoma } \\
\text { (RCC) }\end{array}$ & 10 & Complete response & 38 \\
\hline $\begin{array}{l}\text { Hepatocellular } \\
\text { carcinoma (HCC) }\end{array}$ & 13 & $\begin{array}{l}\text { Reduced tumor } \\
\text { volume; } \\
\text { Improved } \\
\text { symptoms; } \\
\text { Decreased HBV-DNA } \\
\text { load }\end{array}$ & 14 \\
\hline $\begin{array}{l}\text { Relapsed } \\
\text { Hodgkin's } \\
\text { disease (HD); } \\
\text { Non-Hodgkin's } \\
\text { lymphoma (NHL) }\end{array}$ & 9 & $\begin{array}{l}\text { Partial response (2); } \\
\text { Stable disease (3) }\end{array}$ & 39 \\
\hline $\begin{array}{l}\text { Relapsed acute } \\
\text { myeloid leukemia } \\
\text { (AML); } \\
\text { Chronic myeloid } \\
\text { leukemia (CML); } \\
\text { HD; } \\
\text { Acute } \\
\text { lymphoblastic } \\
\text { leukemia (ALL); } \\
\text { Myelodisplastic } \\
\text { syndrome (MDS) }\end{array}$ & 11 & $\begin{array}{l}\text { Complete response } \\
(3) ; \\
\text { Stable disease (1) }\end{array}$ & 40 \\
\hline HCC & 85 & $\begin{array}{l}\text { Decreased } \\
\text { recurrence rate }\end{array}$ & 41 \\
\hline Resected HCC & 127 & Increased DFS & 42 \\
\hline $\begin{array}{l}\text { Metastatic RCC; } \\
\text { HCC }\end{array}$ & 12 & $\begin{array}{l}\text { Complete response } \\
\text { (3); Partial } \\
\text { response (1); } \\
\text { Stable disease (2) }\end{array}$ & 43 \\
\hline AML; ALL & 5 & Partial response (1) & 44 \\
\hline $\begin{array}{l}\text { B-cell NHL; } \\
\text { AML; Multiple } \\
\text { myeloma; } \\
\text { ALL; MDS; HD; } \\
\text { Chronic lymphoid } \\
\text { leukemia } \\
\end{array}$ & 18 & $\begin{array}{l}\text { Complete response } \\
\text { (5) }\end{array}$ & 45 \\
\hline B-cell NHL & 9 & Complete response & 46 \\
\hline Multiple myeloma & 1 & Complete response & 47 \\
\hline
\end{tabular}

Moreover, a few studies have explored the therapeutic benefit of CIK cells against viral infection that cause mortality and morbidity in immunecompromised individuals. As such, CIK cell therapy has been shown to be effective in targeted lysis of cells infected with human immunodeficiency virus ${ }^{48}$. Epstein-Barr virus ${ }^{49}$ or cytomegalovirus $^{50}$. This antiviral activity could be due to the production of IFN- $\gamma$, TNF- $\alpha$, perforin and granzyme B by CIK cells.

\section{CONTRAINDICATIONS OF CIK CELL IMMUNOTHERAPY}

There are many clinical studies using the CIK cells as immunotherapy. Till date, no severe side effects have been reported after CIK treatment. The most common side-effects were fever, chills, headache, rash, nausea, and vomiting occurring during or after transfusion. These could easily be treated with symptomatic therapy in case they did not resolve on their own within 24 hours ${ }^{51,52}$. This indicates that CIK therapy is safe for clinical application although larger population cohorts should be investigated.

\section{CONCLUSIONS}

CIK cells were used as an adoptive immunotherapy against various cancers and some viral infections. However, the effectiveness varies with different clinical settings, mainly due to different approaches followed in their generation. Hence, further studies are warranted to enhance the expansion and cytolytic function of the CIK cells. Moreover, the beneficial use of CIK cell in various viral infections needs to be investigated.

\section{Competing interests}

We declare no competing interest.

\section{Financial disclosure}

No funding source to declare.

\section{REFERENCES}

1. Qian X, Wang X, Jin H. Cell transfer therapy for cancer: Past, present, and future. J Immunol Res. 2014; 2014: 525913.

2. Maus MV, Fraietta JA, Levine BL, Kalos M, Zhao Y, June $\mathrm{CH}$. Adoptive immunotherapy for cancer or viruses. Annu Rev Immunol. 2014; 32: 189-225.

3. Sangiolo D. Cytokine induced killer cells as promising 
immunotherapy for solid tumors. J Cancer. 2011; 2: 363-8.

4. Schmidt-Wolf IG, Negrin RS, Kiem HP, Blume KG, Weissman IL. Use of a SCID mouse/human lymphoma model to evaluate cytokine-induced killer cells with potent antitumor cell activity. J Exp Med. 1991; 174(1): 139-49.

5. Schmidt-Wolf IG, Lefterova P, Mehta BA, Fernandez LP, Huhn D, Blume KG, et al. Phenotypic characterization and identification of effector cells involved in tumor cell recognition of cytokine-induced killer cells. Exp Hematol. 1993; 21(13): 1673-9.

6. Schmidt-Wolf GD, Negrin RS, Schmidt-Wolf IG. Activated T cells and cytokine-induced CD3+CD56+ killer cells. Ann Hematol. 1997; 74(2): 51-6.

7. Schmidt-Wolf IG, Lefterova P, Johnston V, Huhn D, Blume KG, Negrin RS. Propagation of large numbers of T cells with natural killer cell markers. Br J Haematol. 1994; 87(3): 453-8.

8. Smith C, Okern G, Rehan S, Beagley L, Lee SK, Aarvak $\mathrm{T}$ et al. Ex vivo expansion of human $\mathrm{T}$ cells for adoptive immunotherapy using the novel Xeno-free CTS immune cell serum replacement. Clin Transl Immunology. 2015; 4(1): e31.

9. Lu PH, Negrin RS. A novel population of expanded human CD3+CD56+ cells derived from $\mathrm{T}$ cells with potent in vivo antitumor activity in mice with severe combined immunodeficiency. J Immunol. 1994; 153(4): 1687-96.

10. Baume DM, Caligiuri MA, Manley TJ, Daley JF, Ritz J. Differential expression of CD8 alpha and CD8 beta associated with MHC-restricted and non-MHCrestricted cytolytic effector cells. Cell Immunol. 1990; 131(2): 352-65.

11. Sangiolo D, Martinuzzi E, Todorovic M, Vitaggio K, Vallario A, Jordaney $\mathrm{N}$ et al. Alloreactivity and antitumor activity segregate within two distinct subsets of cytokine-induced killer (CIK) cells: Implications for their infusion across major HLA barriers. Int Immunol. 2008; 20(7): 841-8.

12. Gutgemann S, Frank S, Strehl J, Schmidt-Wolf IG. Cytokine-induced killer cells are type II natural killer T cells. Ger Med Sci. 2007; 5: Doc07.

13. Timalsena S, Pluangnooch $\mathrm{P}$, Wongkajornsilp A, Soontrapa K. An additional CD28 costimulatory signal enhances proliferation and cytotoxicity of murine $\mathrm{T}$ cell-derived CIK cells. Asian Pac J Allergy Immunol. 2016.

14. Shi M, Zhang B, Tang ZR, Lei ZY, Wang HF, Feng YY et al. Autologous cytokine-induced killer cell therapy in clinical trial phase I is safe in patients with primary hepatocellular carcinoma. World J Gastroenterol. 2004; 10(8): 1146-51.

15. Li DP, Li W, Feng J, Chen K, Tao M. Adjuvant Chemotherapy With Sequential Cytokine-Induced Killer (CIK) Cells in Stage IB Non-Small Cell Lung Cancer. Oncol Res. 2015; 22(2):67-74.

16. Durrieu L, Gregoire-Gauthier J, Dieng MM, Fontaine F, le DeistF, Haddad E. Human interferon-alphaincreases the cytotoxic effect of CD56(+) cord blood-derived cytokine-induced killer cells on human B-acute lymphoblastic leukemia cell lines. Cytotherapy. 2012; 14(10): 1245-57.

17. Wang L, Huang S, Dang Y, Li M, Bai W, Zhong Z et al. Cord blood-derived cytokine-induced killer cellular therapy plus radiation therapy for esophageal cancer: A case report. Medicine (Baltimore). 2014; 93(28): e340.

18. Jiang J, Wu C, Lu B. Cytokine-induced killer cells promote antitumor immunity. J Transl Med. 2013; 11: 83.

19. Baker J, Verneris MR, Ito M, Shizuru JA, Negrin RS. Expansion of cytolytic CD8(+) natural killer T cells with limited capacity for graft-versus-host disease induction due to interferon gamma production. Blood. 2001; 97(10): 2923-31.

20. Joshi PS, Liu JQ, Wang Y, Chang X, Richards J, Assarsson $\mathrm{E}$, et al. Cytokine-induced killer T cells kill immature dendritic cells by TCR-independent and perforindependent mechanisms. J Leukoc Biol. 2006; 80(6): 1345-53.

21. Helms MW, Prescher JA, Cao YA, Schaffert S, Contag CH. IL-12 enhances efficacy and shortens enrichment time in cytokine-induced killer cell immunotherapy. Cancer Immunol Immunother. 2010; 59(9): 1325-34.

22. Marten A, Ziske C, Schottker B, Renoth S, Weineck S, Buttgereit $\mathrm{P}$ et al. Interactions between dendritic cells and cytokine-induced killer cells lead to an activation of both populations. J Immunother. 2001; 24(6): 50210. 
23. Li H, Yu JP, Cao S, Wei F, Zhang P, An XM et al. CD4 $+\mathrm{CD} 25+$ regulatory $\mathrm{T}$ cells decreased the antitumor activity of cytokine-induced killer (CIK) cells of lung cancer patients. J Clin Immunol. 2007; 27(3): 317-26.

24. Tao Q Chen T, Tao L, Wang H, Pan Y, Xiong S et al. IL-15 improves the cytotoxicity of cytokine-induced killer cells against leukemia cells by upregulating CD3+CD56+ cells and downregulating regulatory $\mathrm{T}$ cells as well as IL-35. J Immunother. 2013; 36(9): 4627.

25. Lin G, Wang J, Lao X, Wang J, Li L, Li S et al. Interleukin-6 inhibits regulatory T cells and improves the proliferation and cytotoxic activity of cytokineinduced killer cells. J Immunother. 2012; 35(4): 33743.

26. Rettinger E, Kuci S, Naumann I, Becker P, Kreyenberg $\mathrm{H}$, Anzaghe $\mathrm{M}$ et al. The cytotoxic potential of interleukin-15-stimulated cytokine-induced killer cells against leukemia cells. Cytotherapy. 2012; 14(1): 91-103.

27. Rettinger E, Meyer V, Kreyenberg H, Volk A, Kuci S, Willasch A et al. Cytotoxic capacity of IL-15-stimulated cytokine-induced killer cells against human acute myeloid leukemia and rhabdomyosarcoma in humanized preclinical mouse models. Front Oncol. 2012; 2: 32.

28. Zhao N, Zhao MF, Rajbhandary S, Lu WY, Zhu HB, Xiao $\mathrm{X}$ et al. Effects of humanized interleukin 21 on antileukemic activity of cytokine induced killer cells and the mechanism. Zhonghua Xue Ye Xue Za Zhi. 2012; 33(10): 823-8.

29. Lefterova $P$, Marten A, Buttgereit $P$, Weineck S, Scheffold C, Huhn D et al. Targeting of natural killerlike $\mathrm{T}$ immunologic effector cells against leukemia and lymphoma cells by reverse antibody-dependent cellular cytotoxicity. J Immunother. 2000; 23(3): 30410.

30. Yuanying Y, Lizhi N, Feng M, Xiaohua W, Jianying Z, Fei Y et al. Therapeutic outcomes of combining cryotherapy, chemotherapy and DC-CIK immunotherapy in the treatment of metastatic non-small cell lung cancer. Cryobiology. 2013; 67(2): 235-40.

31. Chen B, Liu L, Xu H, Yang Y, Zhang L, Zhang F. Effectiveness of immune therapy combined with chemotherapy on the immune function and recurrence rate of cervical cancer. Exp Ther Med.
2015; 9(3): 1063-67.

32. Wang H, Feng F, Zhu M, Wang R, Wang X, Wu Y et $a l$. Therapeutic efficacy of dendritic cells pulsed by autologous tumor cell lysate in combination with CIK cells on advanced renal cell carcinoma. Xi Bao Yu Fen Zi Mian Yi Xue Za Zhi. 2015; 31(1): 67-71.

33. Gao D, Li C, Xie X, Zhao P, Wei X, Sun Wet al. Autologous tumor lysate-pulsed dendritic cell immunotherapy with cytokine-induced killer cells improves survival in gastric and colorectal cancer patients. PLoS One. 2014; 9(4): e93886.

34. Pan Y, Tao Q Wang H, Xiong S, Zhang R, Chen T et al. Dendritic cells decreased the concomitant expanded Tregs and Tregs related IL-35 in cytokine-induced killer cells and increased their cytotoxicity against leukemia cells. PLoS One. 2014; 9(4): e93591.

35. Mehta BA, Schmidt-Wolf IG, Weissman IL, Negrin RS. Two pathways of exocytosis of cytoplasmic granule contents and target cell killing by cytokine-induced CD3+ CD56+ killer cells. Blood. 1995; 86(9): 3493-9.

36. Sun S, Li XM, Li XD, Yang WS. Studies on inducing apoptosis effects and mechanism of CIK cells for MGC-803 gastric cancer cell lines. Cancer Biother Radiopharm. 2005; 20(2): 173-80.

37. Zhang Y, Wang J, Wang Y, Lu XC, Fan H, Liu Y et al. Autologous CIK cell immunotherapy in patients with renal cell carcinoma after radical nephrectomy. Clin Dev Immunol. 2013; 2013: 195691.

38. Schmidt-Wolf IG, Finke S, Trojaneck B, Denkena A, Lefterova P, Schwella N et al. Phase I clinical study applying autologous immunological effector cells transfected with the interleukin-2 gene in patients with metastatic renal cancer, colorectal cancer and lymphoma. Br J Cancer. 1999; 81(6): 1009-16.

39. Leemhuis T, Wells S, Scheffold C, Edinger M, Negrin RS. A phase I trial of autologous cytokine-induced killer cells for the treatment of relapsed Hodgkin disease and non-Hodgkin lymphoma. Biol Blood Marrow Transplant. 2005; 11(3): 181-7.

40. Introna M, Borleri G, Conti E, Franceschetti M, Barbui AM, Broady R et al. Repeated infusions of donorderived cytokine-induced killer cells in patients relapsing after allogeneic stem cell transplantation: A phase I study. Haematologica. 2007; 92(7): 952-9.

41. Weng DS, Zhou J, Zhou QM, Zhao M, Wang QJ, Huang 
LX, et al. Minimally invasive treatment combined with cytokine-induced killer cells therapy lower the shortterm recurrence rates of hepatocellular carcinomas. $J$ Immunother. 2008; 31(1): 63-71.

42. Hui D, Qiang L, Jian W, Ti Z, Da-Lu K. A randomized, controlled trial of postoperative adjuvant cytokineinduced killer cells immunotherapy after radical resection of hepatocellular carcinoma. Dig Liver Dis. 2009; 41(1): 36-41.

43. Olioso P, Giancola R, Di Riti M, Contento A, Accorsi $\mathrm{P}$, Iacone A. Immunotherapy with cytokine induced killer cells in solid and hematopoietic tumours: A pilot clinical trial. Hematol Oncol. 2009; 27(3): 130-9.

44. Introna $\mathrm{M}$, Pievani $\mathrm{A}$, Borleri G, Capelli $\mathrm{C}$, Algarotti A, Mico $C$, et al. Feasibility and safety of adoptive immunotherapy with CIK cells after cord blood transplantation. Biol Blood Marrow Transplant. 2010; 16(11): 1603-7.

45. Laport GG, Sheehan K, Baker J, Armstrong R, Wong $\mathrm{RM}$, Lowsky $\mathrm{R}$, et al. Adoptive immunotherapy with cytokine-induced killer cells for patients with relapsed hematologic malignancies after allogeneic hematopoietic cell transplantation. Biol Blood Marrow Transplant. 2011; 17(11): 1679-87.

46. Lu XC, Yang B, Yu RL, Chi XH, Tuo S, Tuo CW, et al. Clinical study of autologous cytokine-induced killer cells for the treatment of elderly patients with diffuse large B-cell lymphoma. Cell Biochem Biophys. 2012; 62(1): 257-65.
47. Yang B, Wang J, Cai LL, Zhu HL, Yu RL, Chi XH, et al. Treatment of multiple solitary plasmacytomas with cytokine-induced killer cells. Cytotherapy. 2014; 16(2): 278-84.

48. Jiang Y, Cui X, Cui C, Zhang J, Zhou F, Zhang Z, et al. The function of CD3+CD56+ NKT-like cells in HIV-infected individuals. Biomed Res Int. 2014; 2014: 863625.

49. Petvises S, Pakakasama S, Wongkajornsilp A, Sirireung S, Panthangkool W, Hongeng S. Ex vivo generation of cytokine-induced killer cells (CD3+ CD56+) from post-stem cell transplant pediatric patients against autologous-Epstein-Barr virus-transformed lymphoblastoid cell lines. Pediatr Transplant. 2007; 11(5): 511-7.

50. Pfirrmann V, Oelsner S, Rettinger E, Huenecke S, Bonig $\mathrm{H}$, Merker $\mathrm{M}$, et al. Cytomegalovirus-specific cytokine-induced killer cells: Concurrent targeting of leukemia and cytomegalovirus. Cytotherapy. 2015; 17(8): 1139-51.

51. Shi L, Zhou Q, Wu J, Ji M, Li G, Jiang J, et al. Efficacy of adjuvant immunotherapy with cytokine-induced killer cells in patients with locally advanced gastric cancer. Cancer Immunol Immunother. 2012; 61(12): 2251-9.

52. Jakel CE, Vogt A, Gonzalez-Carmona MA, Schmidt-Wolf IG. Clinical studies applying cytokine-induced killer cells for the treatment of gastrointestinal tumors. $J$ Immunol Res. 2014; 2014: 897214. 